\title{
Analisis Probabilitas Penumpang Bus di Dalam dan di Luar Terminal Oebobo Berbasis Karakteristik Sosial Ekonomi dan Aksesibilitas dengan Metode Revealed Preference
}

\author{
Gaspar Y. K. Tuames dan Hera Widiyastuti \\ Departemen Teknik Sipil, Institut Teknologi Sepuluh Nopember (ITS) \\ Corresponding Author: tuames_gaspar@yahoo.com
}

ARTIKEL INFO
Informasi Artikel

formasi Artike

Artikel masuk: 22-7-19

Artikel revisi: -

Artikel diterima: 26-12-19

\section{Kata Kunci}

Penumpang Bus, Karakteristik, Probabilitas, Dalam Terminal, Luar Terminal, Revealed Preference, Logit Biner

\begin{abstract}
ABSTRAK
Studi ini akan mengetahui karaktristik penumpang bus di dalam terminal Oebobo dan di luar terminal (Pertigaan Oesapa) serta probabilitas pemilihan lokasi menumpang bus berbasis karakteristik sosial ekonomi dan aksesbilitas. Penelitian ini diawali dengan pengumpulan data primer yang didapatkan dari hasil pengisian kuesioner oleh responden dengan menggunakan teknik revealed preference. Data primer kemudian diolah menggunakan analisis regresi logistik untuk mendapatkan nilai probabilitas. Dari hasil analisa, terlihat bahwa penumpang bus lebih banyak memilih lokasi menumpang di di luar terminal (Pertigaan Oesapa) yakni sebesar 77,65\%. Probalitas penumpang yang memilih lokasi menumpang dipengaruhi oleh variabel tarif menuju lokasi menumpang bus dan waktu tunggu bus. Untuk tarif $<$ Rp.5000 nilai probabilitas sebesar 76,25\% dan tarif >Rp.20000 nilai probabilitas sebesar 92,39\% memilih di Pertigaan Oesapa. Semakin besar tarif menuju lokasi menumpang maka berpotensi lebih tinggi bagi penumpang bus untuk memilih lokasi menumpang di Pertigaan Oesapa. Sedangkan berdasarkan variabel waktu tunggu bus semakin cepat waktu menunggu bus maka berpotensi lebih tinggi bagi penumpang bus untuk memilih lokasi menumpang di Pertigaan Oesapa dengan nilai probabilitas untuk waktu tunggu <30menit 97,09\% memilih lokasi menumpang di Pertigaan Oesapa dan untuk waktu tunggu $>120$ menit nilai probabilitas sebesar 91,49\% memilih lokasi menumpang di Terminal Oebobo.
\end{abstract}

\section{PENDAHULUAN}

Fungsi terminal bagi penumpang adalah untuk kenyamanan menunggu, kenyamanan perpindahan dari satu moda atau kendaraan lain, tempat fasilitas-fasilitas informasi dan fasilitas kendaraan pribadi [1]. Pada beberapa Kota di Indonesia, fungsi terminal bus bagi kenyamanan penumpang belum efektif karena sebagian aktifitas menaikkan dan menurunkan penumpang terjadi di luar terminal. Aktifitas ini juga terjadi di terminal bus Oebobo Kota Kupang. Dalam melakukan aktifitasnya bus AKDP yang seharusnya berhenti di dalam Terminal Oebobo, ternyata sebagian besar melakukannya di luar terminal (Pertigaan Oesapa).

Kondisi ini masih terjadi terus menerus sampai saat ini meskipun dilakukan penertiban di dari pihak Dinas Perhubungan Provinsi NTT, akantetapi para pengemudi tidak menaati peraturan yang ada. Oleh karena itu perlu dilakukan analisa regresi logistik biner untuk mengatahui probablitas penumpang bus dalam memilih lokasi menumpang bus di dalam terminal Oebobo maupun di luar terminal (Pertigaan Oesapa).

\section{METODE PENELITIAN}

Metode yang digunakan dalam penelitian ini meliputi identifikasi masalah, rumusan masalah, studi literatur, penyusunan kuisioner, penentuan jumlah sampel, pengumpulan data (primer data dan sekunder) dan analisa data. Identifikasi masalah adalah tahapan awal yang dilakukan pada penelitian ini, pada tahapan ini penetuan masalah yaitu belum efeketifnya terminal bus Oebobo karena masih banyak penumpang yang memilih menunggu dan menumpang bus di luar terminal terutama sekitar Pertigaan Oesapa. Studi literatur yakni teori mengenai analisis probabilitas menggunakan metode Revealed Preference (RP) [2], model logistik biner dan aksesibilitas. Selain dasar teori tersebut diperlukan juga studi dari penelitian sebelumnya yang berkaitan dengan kasus penelitian ini yang nantinya akan digunakan sebagai acuan dalam pelaksanaan penelitian.

Jumlah sampel ditentukan menggunakan rumus Slovin [3]. Populasi pada penelitian ini adalah penumpang harian puncak di Terminal Oebobo sebanyak 557 penumpang [4]. Untuk menentukan jumlah sampel digunakan dengan perhitungan sebagai berikut:

$$
\begin{aligned}
& n=\frac{\mathrm{N}}{1+\mathrm{N}(\mathrm{e})^{2}} \\
& n=\frac{557}{1+557(0.10)^{2}} \\
& n=84,77 \approx 85 \text { Responden } \\
& \text { dimana: }
\end{aligned}
$$


$\mathrm{n}=$ jumlah sampel

$\mathrm{N}=$ jumlah populasi

$\mathrm{E}=$ persen tingkat kesalahan (0,10 atau $10 \%)$

Total jumlah sampel adalah 170 responden dengan 85 responden di dalam terminal bus Oebobo dan 85 sampel di Pertigaan Oesapa. Jumlah sampel ini kemudian dibagi berdasarkan Kota tujuan. Proporsi jumlah responden berdasarkan Kota tujuan dapat dilihat pada Tabel 1.

\begin{tabular}{lccc}
\multicolumn{3}{c}{ Tabel 1. Proporsi Jumlah Responden } \\
\cline { 2 - 3 } \multicolumn{1}{c}{ Kota Tujuan } & \multicolumn{2}{c}{ Jumlah Responden } & Total \\
\cline { 2 - 3 } & dalam terminal & $\begin{array}{c}\text { luar } \\
\text { terminal }\end{array}$ & \\
\hline Atambua & 25 & 25 & 50 \\
Kefamenanu & 25 & 25 & 50 \\
SoE & 20 & 20 & 40 \\
Betun/Besikama & 10 & 10 & 20 \\
Lainnya & 5 & 5 & 10 \\
\hline Total & 85 & 85 & 170 \\
\hline
\end{tabular}

Pengambilan data dilakukan dengan penyerahan kuisoner dan wawancara langsung kepada penumpang bus pada dua lokasi penelitian yaitu di dalam Terminal Oebobo maupun di luar terminal (Pertigaan Oesapa). Dari hasil survey kuisoner dan wawancara ini digunakan untuk di analisa tahapan berikutnya yaitu analisa karakteristik sosial ekonomi penumpang bus berupa analisis deskriptif data pribadi para penumpang yag diperoleh dari survey wawancara pada responden, data tersebut diantaranya usia responden, jenis kelamin, pekerjaan, pendidikan terakhir, pendapatan bulanan, data perjalanan dari perjalanan dari asal perjalanan menuju lokasi menumpang bus.

Analisis regresi logit biner (Binary Logistic Regression) digunakan untuk mengetahui persentase probabilitas responden yang memilih lokasi menupang bus di dalam Terminal Oebobo atau di luar terminal (Pertigaan Oesapa). Selain itu analisis regresi logistik biner juga dapat digunakan untuk mengetahui faktorfaktor yang dapat mempengaruhi responden untuk memilih lokasi menumpang bus di dalam Terminal Oebobo atau di Pertigaan Oesapa. Untuk menentukan perkiraan nilai probabilitas perpindahan moda dapat dihitung dengan menggunakan rumus [5][6] sebagai berikut:

$\operatorname{Logit}(p)=\ln \left[\frac{\mathrm{p}}{1-\mathrm{p}}\right]=\beta_{0}+\beta_{1} X_{1}$

Dimana: $\quad \beta 0+\beta 1=$ Data yang bersifat biner yang merupakan variabel terikat dengan dua respon, di dalam Terminal Oebobo (0) atau luar terminal/Pertigaan Oesapa (1). $(X)=$ Merupakan variabel bebas, yakni faktor pengaruh dalam pemilihan lokasi menumpang bus. Setelah perhitungan ini selesai maka didapatkan hasil nilai (exp) eksponensial yang akan dipakai untuk menghitung perkiraan besar nilai probabilitas menggunakan rumus [5][6]sebagai berikut:

$$
P=\frac{\exp ^{\operatorname{logit}(p)}}{1+\exp ^{\operatorname{logit}(p)}}
$$

Penentukan faktor yang berpengaruh antara variabel bebas dengan variabel terikatnya, dapat ditentukan dengan membandingkan nilai signifikannya, yaitu jika nilai sig. $<\alpha$, dengan toleransi nilai $\alpha=5 \%$. Maka variabel tersebut berpengaruh, namun jika nilai sig. $>\alpha$ maka variabel tersebut tidak berpengaruh. Nilai sig. didapat dari hasil perhitungan sebelumnya tentang perkiraan besar nilai probabilitas. Dalam pelaksanaan perhitungan regresi logistik biner tersebut dilakukan dengan menggunakan bantuan program SPSS.

\section{HASIL DAN PEMBAHASAN}

\section{A. Karakteristik Umum Penumpang Bus Jenis Kelamin}

Hasil survey menunjukkan jenis kelamin penumpang di dalam Terminal Oebobo diperoleh 39 orang $(22,94 \%)$ laki-laki dan 46 orang $(27,06 \%)$ perempuan. Di Pertigaan Oesapa diperoleh 42 orang $(24,71 \%)$ laki-laki dan 43 orang $(25,29 \%)$ perempuan. Distribusi jenis kelamin responden dapat dilihat pada Gambar 1.

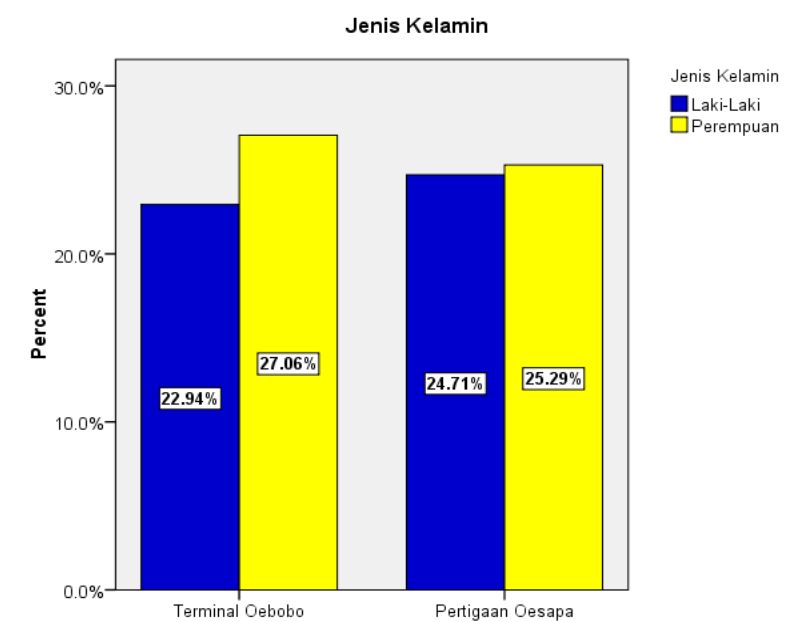

Gambar 1. Grafik Karakteristik Penumpang Bus Berdasarkan Jenis Kelamin.

\section{B. Usia}

Usia penumpang di dalam Terminal Oebobo diperoleh paling banyak $21-40$ tahun $(42,36 \%)$ dan paling sedikit $<20$ tahun $(8,24 \%)$. Sedangkan di Pertigaan Oesapa diperoleh usia penumpang paling banyak 21-40 tahun $(48,24 \%)$ dan paling sedikit $>55$ tahun $(10,58 \%)$. Distribusi usia penumpang dapat dilihat pada Gambar 2.

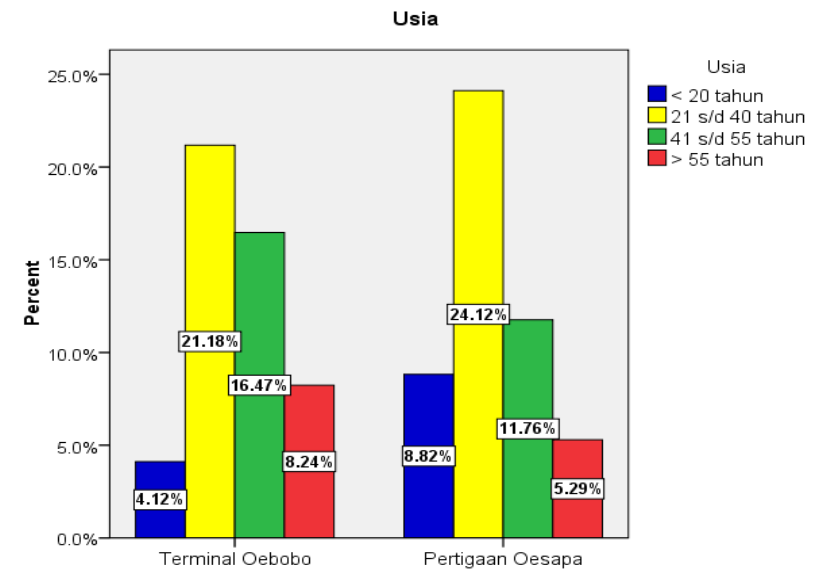

Gambar 2. Grafik Karakteristik Penumpang Bus Berdasarkan Usia.

\section{Tingkat Pendidikan}

Penumpang bus di dalam Terminal Oebobo diperoleh tingkat pendidikan paling banyak adalah SMA/sederajat $(40,00 \%)$ dan paling sedikit SMP/sederajat (18,82\%). Sedangkan penumpang di Pertigaan Oesapa paling banyak adalah SMA/sederajat $(55,53 \%)$ dan paling sedikit SMP/sederajat $(9,42 \%)$. Distribusi tingkat pendidikan responden dapat dilihat pada Gambar 3. 


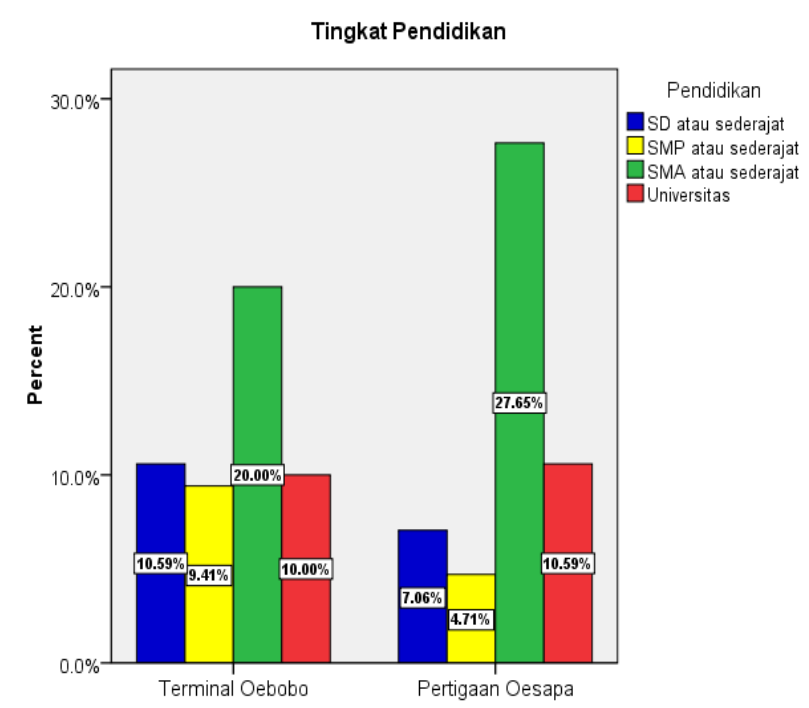

Gambar 3. Grafik Karakteristik Penumpang Bus Berdasarkan Tingkat Pendidikan.

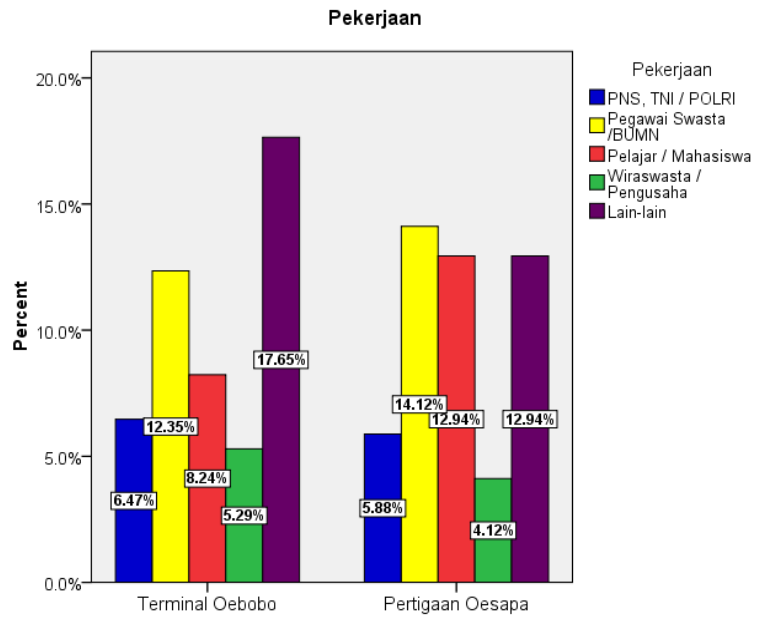

Gambar 4. Grafik Karakteristik Penumpang Bus Berdasarkan Pekerjaan.

\section{Pekerjaan}

Penumpang bus di dalam Terminal Oebobo diperoleh pekerjaan paling banyak adalah pekerjaan seperti ibu rumah tangga, tukang dan petani $(35,30 \%)$ dan paling sedikit wiraswasta/pengusaha $(10,58 \%)$. Sedangkan penumpang di Pertigaan Oesapa diperoleh pekerjaan paling banyak pegawai swasta/BUMN $(28,24 \%)$ dan paling sedikit pekerjaan wiraswasta/pengusaha $(8,24 \%$. Distribusi pekerjaan responden dapat dilihat pada Gambar 4.

\section{E. Penghasilan}

Penumpang di dalam Terminal Oebobo diperoleh penghasilan paling banyak adalah penghasilan paling banyak adalah $<2$ juta $(41,18 \%)$ dan tidak ada yang berpenghasilan $>6$ juta $(0,00 \%)$. Penumpang di Pertigaan Oesapa diperoleh penghasilan paling banyak adalah $<2$ juta $(49,42 \%)$ dan tidak ada yang berpenghasilan $>6$ juta $(0,00 \%)$. Distribusi penghasilan responden dapat dilihat pada Gambar 5.

\section{F. Karaktristik Perjalanan Menuju Lokasi Menumpang Lokasi Asal}

Berdasarkan hasil survey asal perjalanan penumpang bus di dalam Terminal Oebobo menunjukkan bahwa responden terbanyak berasal dari Kecamatan Oebobo 40 orang $(47,06 \%)$, dan paling sedikit berasal dari

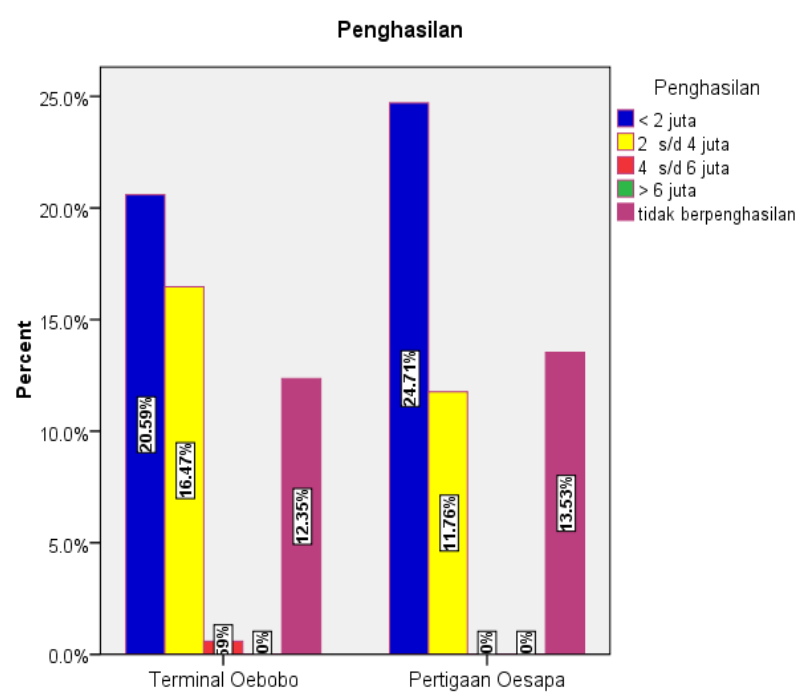

Gambar 5. Grafik Karakteristik Penumpang Bus Berdasarkan Penghasilan.

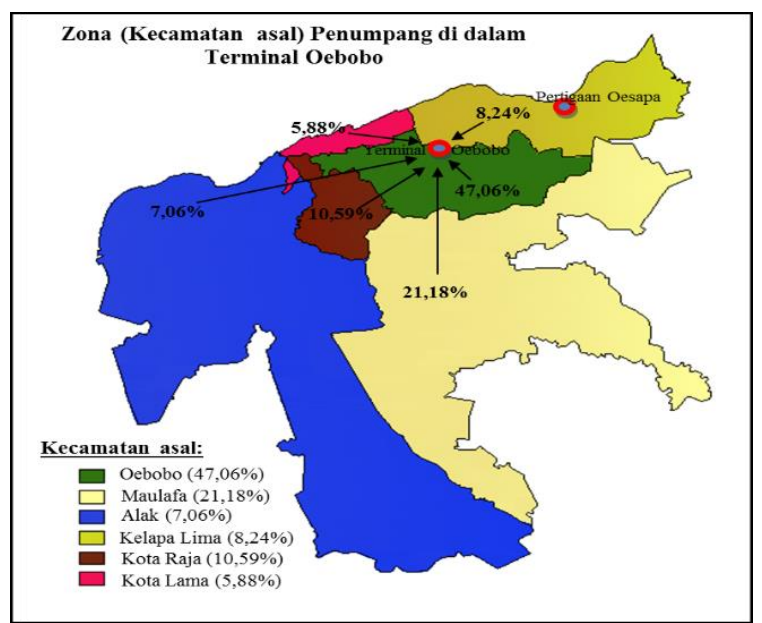

Gambar 6. Lokasi Asal Perjalanan Penumpang bus di dalam Terminal Oebobo.

Kecamatan Kota Lama 5 orang $(5,88 \%)$. Berikut adalah Gambar 6 distribusi asal perjalanan penumpang di dalam Terminal Oebobo.

Lokasi asal perjalanan penumpang bus di Pertigaan Oesapa terbanyak berasal dari berasal Kecamatan Kelapa Lima sebanyak 29 orang (34,12\%), dan paling sedikit berasal dari Kecamatan Alak 4 orang $(4,71 \%)$. Berikut adalah Gambar 7 distribusi asal perjalanan penumpang di Pertigaan Oesapa.

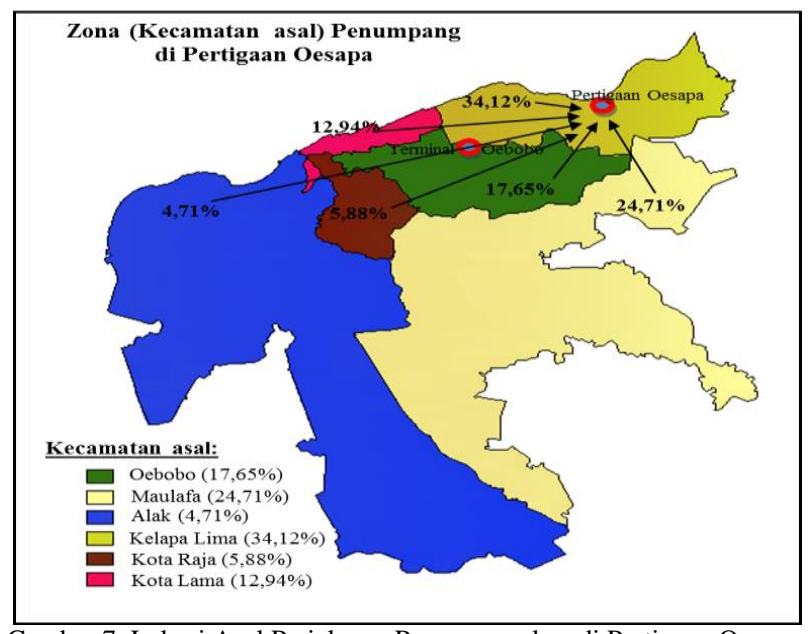

Gambar 7. Lokasi Asal Perjalanan Penumpang bus di Pertigaan Oesapa. 


\section{G. Moda Menuju Lokasi Menumpang Bus}

Berdasarkan hasil survey diperoleh data moda yang digunakan menuju lokasi menumpang di dalam Terminal Oebobo lebih banyak menggunakan bemo/angkot 32 orang $(18,82 \%)$, dan paling sedikit berjalan kaki 1 orang (0,59\%). Demikian juga di Pertigaan Oesapa paling banyak menggunakan bemo/angkot 29 orang $(17,06 \%)$, dan paling sedikit berjalan kaki 3 orang $(1,76 \%)$. Distribusi moda yang digunakan menuju lokasi menumpang bus dapat dilihat pada Gambar 8.

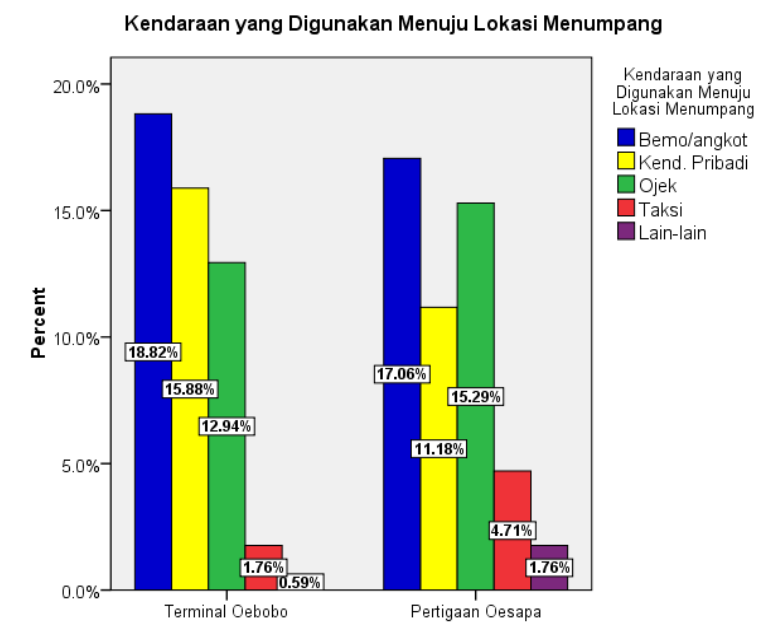

Gambar 8. Grafik Moda yang Digunakan Menuju Lokasi Menumpang Bus.

\section{H. Waktu Tempuh Menuju Lokasi Menumpang Bus}

Berdasarkan hasil survey diperoleh waktu perjalanan dari lokasi asal menuju lokasi menumpang bus di Terminal Oebobo rata-rata ditembuh dengan waktu kurang dari 20 menit yaitu 55 orang $(32,35 \%), 20-40$ menit 28 orang $(16,47 \%)$, 40-60 menit 2 orang $(1,18 \%)$, dan tidak ada waktu tempuh di atas 60 menit $(0,00 \%)$. Demikian pula di Pertigaan Oesapa rata-rata ditembuh dengan waktu kurang dari 20 menit yakni 48 orang $(28,24 \%), 20-40$ menit 32 orang $(18,82 \%)$, 40-60 menit 4 orang $(2,35 \%)$, dan $>60$ menit 1 orang $(0,59 \%)$. Grafik waktu tempuh menuju lokasi menumpang bus dapat dilihat pada Gambar 9.

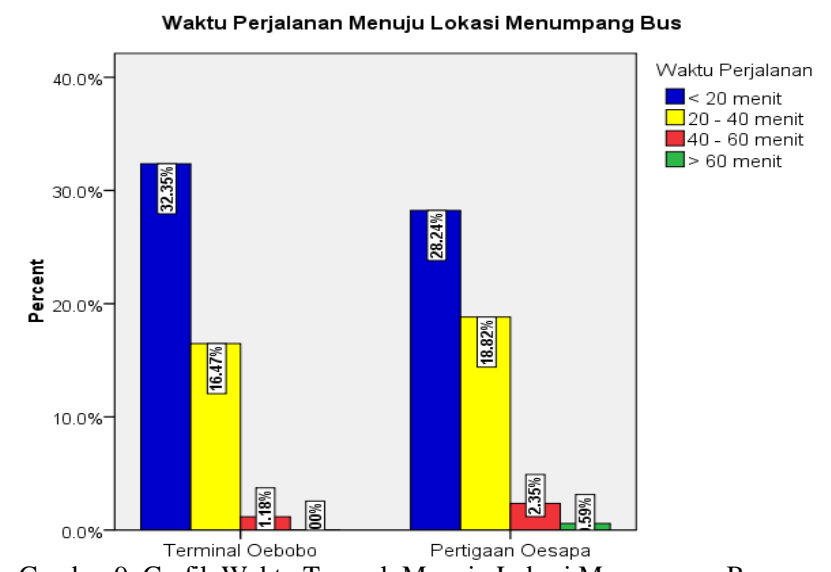

Gambar 9. Grafik Waktu Tempuh Menuju Lokasi Menumpang Bus.

\section{Tarif Perjalanan Menuju Lokasi Menumpang Bus}

Berdasarkan hasil survey diperoleh tarif perjalanan dari lokasi asal menuju lokasi menumpang bus di Terminal Oebobo rata-rata kurang dari Rp.5000,- yaitu 29 orang $(17,06 \%)$, dan tidak membayar karena diantar menggunakan kendaraan pribadi sebanyak 28 orang $(16,47 \%)$. Pada Pertigaan Oesapa tarif atau ongkos perjalanan dari lokasi asal menuju lokasi menumpang bus diperoleh data < Rp.5000 sebanyak 13 orang (7,65\%), Rp.5000 - Rp.10000 sebanyak 24 orang $(14,12 \%)$, dan tidak membayar karena diantar menggunakan kendaraan pribadi sebanyak 22 orang $(12,94 \%)$. Grafik tarif perjalanan menuju lokasi menumpang bus dapat dilihat pada Gambar 10.

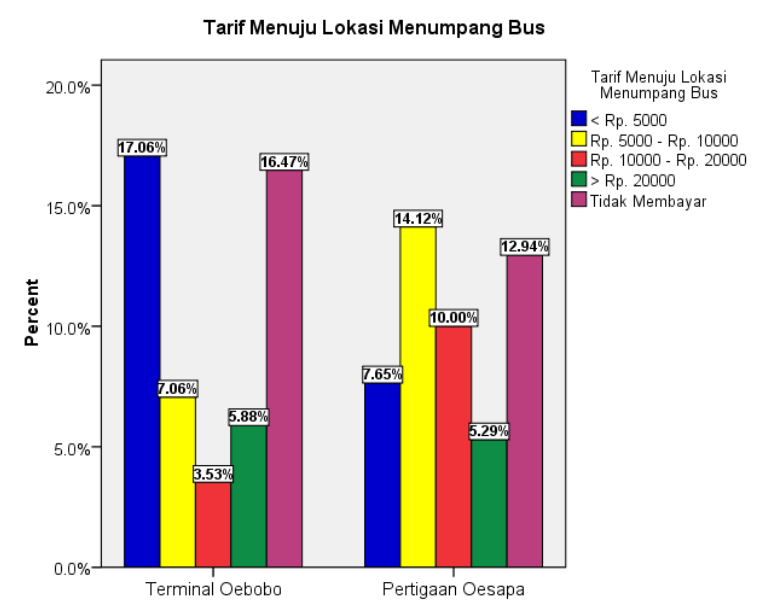

Gambar 10. Grafik Tarif Perjalanan Menuju Lokasi Menumpang Bus.

\section{J. Ketersedian Angkutan Umum/Bemo Menuju Lokasi Menumpang Bus}

Berdasarkan hasil survey diperoleh data sebanyak 60 responden $(35,29 \%)$ menjawab ada rute angkutan umum/bemo, sedangkan 25 responden $(14,71 \%)$ tidak ada rute angkutan umum/bemo dari lokasi asal menuju Terminal Oebobo. Rute Bemo yang melewati terminal Oebobo adalah di antaranya trayek 07, trayek 10 dan trayek 27.

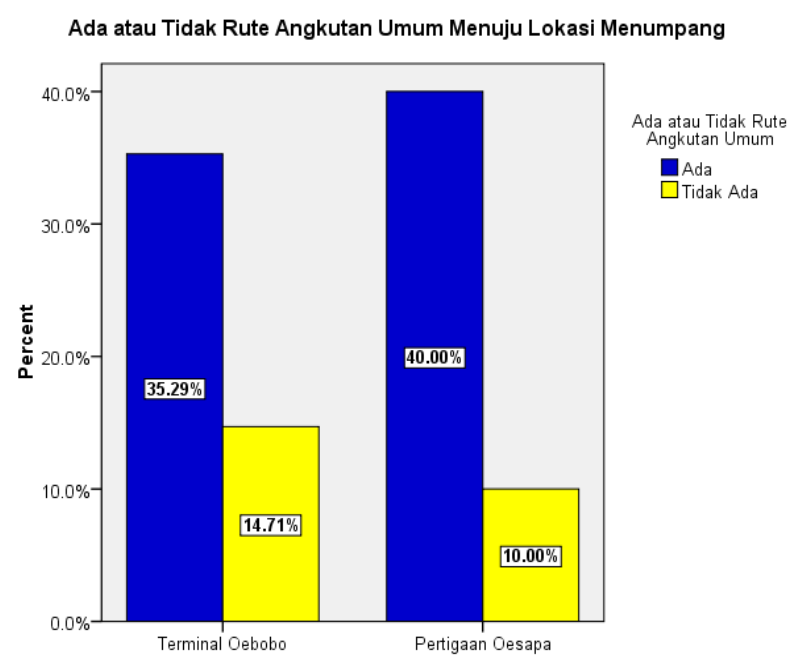

Gambar 11. Grafik Tarif Perjalanan Menuju Lokasi Menumpang Bus.

Pada Pertigaan Oesapa diperoleh sebanyak 68 responden (40\%) menjawab ada rute angkutan umum/bemo, sedangkan 17 responden (10,00\%) menjawab tidak ada rute angkutan umum dari lokasi asal menuju Pertigaan Oesapa. Akses menuju Pertigaan Oesapa menggunakan bemo/angkot dari Kecamatan Maulafa dan Kecamatan Kota Raja (Belo, Sikumana, Naikoten 1, Naikoten 2 Kuanino, dan sekitarnya) menggunakan trayek 01 , trayek 02 atau 05 menuju 
Tabel 2. Hasil Uji Variabel Bebas

\begin{tabular}{|c|c|c|c|c|c|}
\hline No & \multicolumn{2}{|c|}{ Variabel Bebas } & $\begin{array}{c}\text { Hasil } \\
\text { Uji }\end{array}$ & Sig./Tidak Sig. & Ket. \\
\hline 1 & \multicolumn{2}{|l|}{$\begin{array}{l}\text { Jenis } \\
\text { Kelamin }\end{array}$} & 0.254 & Tidak Sig. & - \\
\hline 2 & \multicolumn{2}{|l|}{ Usia } & 0.969 & Tidak Sig. & - \\
\hline \multirow{4}{*}{3} & \multirow{4}{*}{ Pendidikan } & SD & 0.485 & Tidak Sig. & \multirow{4}{*}{ - } \\
\hline & & SMP & 0.208 & Tidak Sig. & \\
\hline & & SMA/SMK & 0.526 & Tidak Sig. & \\
\hline & & Universitas & 0.864 & Tidak Sig. & \\
\hline \multirow{5}{*}{4} & \multirow{5}{*}{ Pekerjaan } & PNS, TNI / Polri & 0.426 & Tidak Sig. & \multirow{5}{*}{-} \\
\hline & & Pegawai Swasta / BUM & 0.182 & Tidak Sig. & \\
\hline & & Pelajar / Mahasiswa & 0.076 & Tidak Sig. & \\
\hline & & Wiras wasta / Pengusah & 0.402 & Tidak Sig. & \\
\hline & & Lain - lain & 0.096 & Tidak Sig. & \\
\hline \multirow{4}{*}{5} & \multirow{4}{*}{ Penghasilar } & $<2$ juta & 0.971 & Tidak Sig. & \multirow{4}{*}{ - } \\
\hline & & $2-4$ juta & 0.869 & Tidak Sig. & \\
\hline & & $4-6$ juta & 1.000 & Tidak Sig. & \\
\hline & & $>6$ juta & 0.714 & Tidak Sig. & \\
\hline \multirow{6}{*}{6} & \multirow{6}{*}{ Lokasi Asal } & Oebobo & 0.142 & Tidak Sig. & \multirow{6}{*}{ - } \\
\hline & & Maulafa & 0.460 & Tidak Sig. & \\
\hline & & Alak & 0.177 & Tidak Sig. & \\
\hline & & Kelapa Lima & 0.012 & Sig. & \\
\hline & & Kota Raja & 0.189 & Tidak Sig. & \\
\hline & & Kota Lama & 0.558 & Tidak Sig. & \\
\hline \multirow{5}{*}{7} & \multirow{5}{*}{$\begin{array}{l}\text { Kendaraan } \\
\text { yang } \\
\text { digunakan } \\
\text { Menuju } \\
\text { Lokasi } \\
\text { Menumpan }\end{array}$} & Angkot/Bemo & 0.022 & Sig. & \multirow{5}{*}{-} \\
\hline & & Kendaraan Pribadi & 0.356 & Tidak Sig. & \\
\hline & & Ojek & 0.002 & Sig. & \\
\hline & & Taksi & 0.126 & Tidak Sig. & \\
\hline & & Lain-lain & 0.702 & Tidak Sig. & \\
\hline \multirow{4}{*}{8} & \multirow{4}{*}{$\begin{array}{l}\text { Waktu } \\
\text { Perjalanan } \\
\text { Menuju } \\
\text { Lokasi } \\
\text { Menumpan }\end{array}$} & $<20$ menit & 0.461 & Tidak Sig. & \\
\hline & & 20 - 40 menit & 0.659 & Tidak Sig. & \\
\hline & & $40-60$ menit & 0.110 & Tidak Sig. & \\
\hline & & $>60$ menit & 1.000 & Tidak Sig. & \\
\hline 9 & \multicolumn{2}{|c|}{$\begin{array}{l}\text { Tarif Menuju Lokasi Menumpang } \\
\text { Bus }\end{array}$} & 0.020 & Sig. & v \\
\hline 10 & \multicolumn{2}{|c|}{$\begin{array}{l}\text { Ada atau Tidak Ada Angkutan } \\
\text { Umum dari Lokasi Asal }\end{array}$} & 0.868 & Tidak Sig. & - \\
\hline 11 & \multicolumn{2}{|c|}{ Lama Waktu Menunggu Bus } & 0.000 & Sig. & $\mathrm{v}$ \\
\hline
\end{tabular}

Terminal Kupang lalu melanjutkan perjalanan ke Pertigaan Oesapa menggunakan trayek 35, Noelbaki dan Baumata. Akses dari kecamatan Alak (Bolok, Tenau, Rumah 7, Fatufeto dan sekitarnya) menggunakan bemo/angkot trayek Kupang-Bolok menuju Terminal Kupang lalu melanjutkan perjalanan ke menggunakan trayek 35, Noelbaki dan Baumata. Dari Kecamatan Oebobo dan Kelapa Lima menggunakan bemo trayek 35, Noelbaki dan Baumata, sedangkan dari Penfui, Baumata dan Bandara Eltari menggunkan trayek Kupang Penfui dan Kupang Baumata. Grafik ketersediaan angkutan umum/bemo menuju lokasi menumpang bus dapat dilihat pada Gambar 11.

\section{K. Probabilitas Pemilihan Lokasi Menumpang Bus}

Berdasarkan total jumlah responden 170 dari kedua lokasi penelitian diperoleh sebanyak 132 orang $(77,65 \%)$ biasa menumpang bus di luar terminal tepatnya di Pertigaan Oesapa sedangkan sisanya 38 orang $(22,35 \%)$ biasa menumpang di dalam Terminal Oebobo.

Dari faktor-faktor yang mempengaruhi responden dalam memilih lokasi menumpang, terlebih dahulu dilakukan pengujian untuk tiap-tiap variabel bebas (independent variables) terhadap variabel terikat (dependent variables), variabel terikat adalah pemilihan lokasi menumpang bus (di dalam Terminal Oebobo $=0$ atau luar terminal/ Pertigaan Oesapa =1). Penentukan faktor yang berpengaruh antara variabel bebas dengan variabel terikatnya, dapat ditentukan dengan membandingkan nilai signifikannya yaitu jika nilai sig. < $\alpha$, dengan toleransi nilai $\alpha=5 \%$. Maka variabel tersebut berpengaruh, namun jika nilai sig. $>\alpha$ maka variabel tersebut tidak berpengaruh. Hasil uji masing-masing variabel dapat dilihat pada pada Tabel 2 .

Berdasarkan Tabel 2 hasil pengujian variabel bebas (independent variable) terhadap variabel terikat (dependent variable), dapat diketahui bahwa variabel bebas yang berpengaruh secara signifikan terhadap variabel terikatnya adalah tarif menuju lokasi menumpang bus dan lama waktu menunggu bus.

\section{Tarif Menuju Lokasi Menumpang Bus}

Hasil uji regresi logistik biner untuk variabel tarif menuju lokasi menumpang bus dilihat pada Tabel 3.

Tabel 3. Hasil Regresi Logit Biner Variabel Tarif Menuju Lokasi Menumpang Bus Variables in the Equation

\begin{tabular}{|c|c|c|c|c|}
\hline & & B & Sig. & $\operatorname{Exp}(B)$ \\
\hline \multirow[t]{2}{*}{$\begin{array}{l}\text { Step } \\
\text { 1a }\end{array}$} & Tarif Menuju Lokasi & 0.066 & 0.020 & 1.069 \\
\hline & Constant & 0.834 & 0.000 & 2.303 \\
\hline
\end{tabular}

Model logit di atas dengan nilai B (tarif menuju lokasi menumpang bus) positif (+) dapat diartikan bahwa setiap kenaikan tarif menuju lokasi menumpang bus mempunyai kemungkinan untuk memilih lokasi menumpang di pertigaan Oesapa lebih banyak daripada di dalam Terminal Oebobo. Nilai $\operatorname{Exp}(B)$ pada variabel ini sebesar 1,069 yang menunjukan responden dengan pertimbangan tarif menuju lokasi menumpang bus memiliki peluang memilih Pertigaan Oesapa lebih tinggi sebesar 1,069 daripada Terminal Oebobo.

Persamaan pemodelan logit pada variabel tarif $<$ Rp5000 (5) menuju lokasi menumpang bus adalah sebagai berikut:

$$
\begin{aligned}
& \operatorname{Logit}(p)=\ln \left[\frac{\mathrm{p}}{1-\mathrm{p}}\right]=\beta_{0}+\beta_{1} X_{1} \\
& =0,834+0.066_{\text {Tarif }}<\text { Rp.5000 } \\
& =0,834+0.066(5) \\
& =1,1664
\end{aligned}
$$

Hasil dari perhitungan logit tersebut dimasukkan kedalam rumus perhitungan probabilitas:

$$
\begin{aligned}
P_{\text {terminal Oebobo }} & =\frac{\exp ^{\text {logit }(p)}}{1+\exp p^{\text {logit }(p)}}=\frac{\exp ^{1,1664}}{1+\exp p^{1,664}} \\
& =0,2375 \approx 23,75 \% \\
P_{\text {pertigaan Oesapa }} & =\frac{1}{1+\exp p^{\text {logit }(p)}}=\frac{1}{1+\exp p^{1,1664}} \\
& =0,7625 \approx 76,25 \%
\end{aligned}
$$

Hasil perhitungan probabilitas lokasi menumpang bus berdasarkan variabel tarif menuju lokasi menumpang bus dapat dilihat pada Gambar 12.

Dari Gambar 12 terlihat bahwa semakin besar tarif menuju lokasi menumpang maka berpotensi lebih tinggi bagi penumpang bus untuk memilih lokasi menumpang di Pertigaan Oesapa dibandingkan dengan di dalam Terminal Oebobo. Penumpang dengan tarif perjalanan menuju lokasi menumpang lebih tinggi, misalkan dengan menggunakan taksi akan cenderung memilih lokasi menumpang di Pertigaan Oesapa. Artinya jika penumpang bus mau mengeluarkan tambahan biaya perjalanan maka langsung memilih lokasi menumpang di Pertigaan Oesapa. Sedangkan penumpang yang memilih lokasi di Terminal Oebobo adalah penumpang di sekitar lokasi terminal dengan biaya perjalanan lebih murah. Demikian juga untuk penumpang yang diantar menggunakan kendaraan pribadi dalam hal ini tidak 
Probabilitas Lokasi Menumpang Bus Berdasarkan Variabel Tarif Menuju Lokasi Menumpang Bus

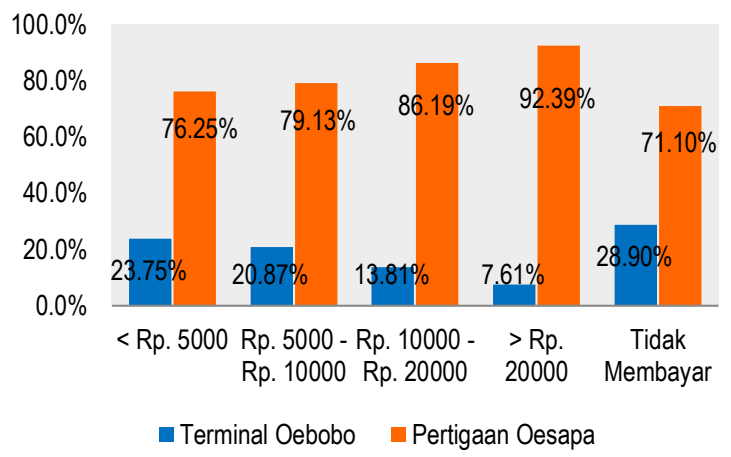

Gambar 12. Grafik Probabilitas Pemilihan Lokasi Menumpang Berdasarkan Variabel Tarif Menuju Lokasi Menumpang Bus.

mengeluarkan biaya tambahan lebih memilih menumpang di Pertigaan Oesapa. Hal ini dapat disebabkan alasan memilih lokasi menumpang di Pertigaan Oesapa karena lebih cepat menunggu bus, penumpang yang lebih dekat menuju Terminal Oebobo lebih berpeluang memilih menumpang di Pertigaan Oesapa selain itu perbedaan biaya transportasi menuju lokasi menumpang yang tidak signifikan sekitar Rp. 3000 - Rp. 10000 sehingga masih dapat dijangkau oleh penumpang bus.

\section{Lama Waktu Tunggu Bus}

Hasil uji regresi logistik biner untuk variabel lama waktu tunggu bus dilihat pada Tabel 4.

Tabel 4. Hasil Regresi Logit Biner Variabel Lama Waktu Tunggu Bus

\begin{tabular}{llllr}
\hline \multicolumn{5}{c}{ Variables in the Equation } \\
\hline Step & Lama Waktu & Sig. & \multicolumn{1}{c}{$\operatorname{Exp}(\mathrm{B})$} \\
1a & $\begin{array}{l}\text { Menunggu Bus } \\
\text { Constant }\end{array}$ & -2.354 & 0.000 & 0.095 \\
& & 4.685 & 0.000 & 108.336 \\
\hline
\end{tabular}

Model logit di atas dengan nilai B (lama waktu menunggu bus) negatif (-) dapat diartikan bahwa setiap kenaikan waktu tunggu bus mempunyai kemungkinan untuk memilih lokasi menumpang di pertigaan Oesapa lebih sedikit daripada di dalam Terminal Oebobo. Nilai Exp (B) pada variabel ini sebesar 0,095 yang menunjukan responden dengan pertimbangan lebih cepat tunggu bus memiliki peluang memilih Pertigaan Oesapa lebih tinggi sebesar 0,095 kali daripada Terminal Oebobo.

Persamaan pemodelan logit pada lama waktu menunggu dan menumpang bus $<30$ menit $(0,5$ jam) menunggu bus adalah sebagai berikut:

$$
\begin{aligned}
\text { Logit }(p) & =\ln \left[\frac{\mathrm{p}}{1-\mathrm{p}}\right]=\beta_{0}+\beta_{1} X_{1} \\
& =4,685-2,354 \text { waktu }<30 \text { menit } \\
& =4,685-2,354(0,5) \\
= & 3,5085
\end{aligned}
$$

Hasil dari perhitungan logit tersebut dimasukkan kedalam rumus perhitungan probabilitas:

$$
\begin{aligned}
P_{\text {terminal Oebobo }} & =\frac{e x p^{\operatorname{logit}(p)}}{1+\exp ^{\log i t(p)}}=\frac{\exp ^{3,5085}}{1+\exp ^{3,5085}} \\
& =0,0291 \approx 2,91 \%
\end{aligned}
$$

$$
\begin{aligned}
P_{\text {terminal Oebobo }}= & \frac{1}{1+\exp ^{\operatorname{logit}(p)}}=\frac{1}{1+\exp ^{3,5085}} \\
& =0,9709 \approx 97,09 \%
\end{aligned}
$$

Hasil perhitungan probabilitas lokasi menumpang bus berdasarkan variabel lama waktu menunggu bus dapat dilihat pada Gambar 13.

Probabilitas Lokasi Menumpang Bus Berdasarkan Variabel Waktu Menunggu Bus

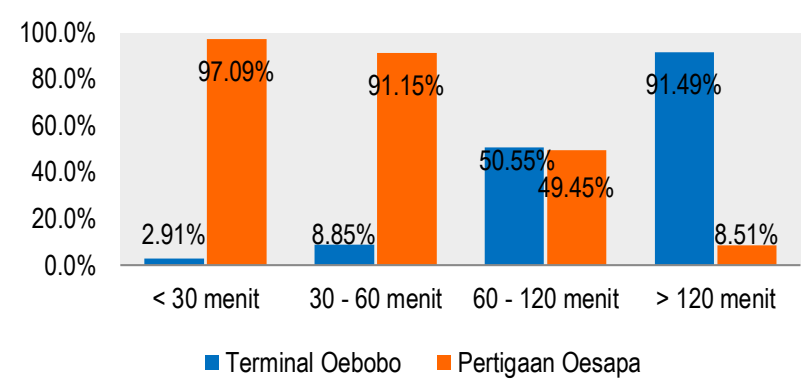

Gambar 13. Grafik Probabilitas Pemilihan Lokasi Menumpang Berdasarkan Variabel Lama Waktu Menunggu Bus

Dari Gambar 13 terlihat bahwa semakin cepat waktu menunggu bus maka berpotensi lebih tinggi bagi penumpang bus untuk memilih lokasi menumpang di Pertigaan Oesapa dibandingkan dengan di dalam Terminal Oebobo. Dari 132 penumpang bus yang memilih lokasi menumpang di Pertigaan Oesapa dengan alasan paling banyak adalah lebih cepat menunggu bus, hal ini disebabkan karena waktu tunggu di Pertigaan Oesapa lebih cepat dibandingkan di dalam Terminal Oebobo, penumpang yang mengiginkan waktu tunggu bus $<1$ jam berpeluang memilih lokasi menumpang di Pertigaan Oesapa, sedangkan penumpang dengan waktu tunggu 1-2 jam peluang memilih di pertigaan Oesapa dan Terminal Oebobo hampir sama, penumpang yang memilih waktu tunggu bus $>2$ jam peluang memilih lokasi menumpang di Terminal Oebobo lebih tinggi, hal ini disebabkan karena alasan lebih nyaman menunggu bus meskipun waktu tunggu tunggu lebih lama. Penumpang di Pertigaan Oesapa menginginkan waktu tunggu yang lebih cepat meskipun tingkat keyamanan lebih rendah di pertigaan Oesapa dari pada di Terminal Oebobo karena harus menunggu di emperan-emperan ruko dan warung makan.

\section{KESIMPULAN}

Berdasarkan hasil penelitian dapat disimpulkan bahwa penumpang bus AKDP dari Kota Kupang menuju beberapa kota tujuan di pulau Timor lebih berpeluang memilih lokasi menumpang di Pertigaan Oesapa daripada di Terminal Oebobo. Terlihat bahwa penumpang bus lebih banyak memilih lokasi menumpang di di luar terminal (Pertigaan Oesapa) yakni sebesar 77,65\%. Variabel waktu tunggu bus yang lebih cepat menjadi alasan utama penumpang bus memilih lokasi di Pertigaan Oesapa, meskipun lokasi asalnya lebih dekat ke Terminal Oebobo. Selain itu faktor perbedaan tarif menuju lokasi menumpang di Terminal Oebobo dan Pertigaan Oesapa yang tidak signifikan juga mempengaruhi penumpang untuk langsung menuju lokasi menumpang di Pertigaan Oesapa. 
Probalitas penumpang yang memilih lokasi menumpang dipengaruhi oleh variabel tarif menuju lokasi menumpang bus dan waktu tunggu bus. Untuk tarif $<$ Rp.5000 nilai probabilitas sebesar $76,25 \%$ dan tarif $>$ Rp.20000 nilai probabilitas sebesar 92,39\% memilih di Pertigaan Oesapa. Semakin besar tarif menuju lokasi menumpang maka berpotensi lebih tinggi bagi penumpang bus untuk memilih lokasi menumpang di Pertigaan Oesapa. Sedangkan berdasarkan variabel lama waktu tunggu bus, semakin cepat waktu menunggu bus maka berpotensi lebih tinggi bagi penumpang bus untuk memilih lokasi menumpang di Pertigaan Oesapa dengan nilai probabilitas untuk waktu tunggu <30menit 97,09\% memilih lokasi menumpang di Pertigaan Oesapa dan untuk waktu tunggu $>120$ menit nilai probabilitas sebesar 91,49\% memilih lokasi menumpang di Terminal Oebobo.

\section{DAFTAR PUSTAKA}

[1] Adisasmita, Perencanaan Infrastruktur Transportasi Wilayah, 2012.

[2] Dewanti et al, Faktor-Faktor yang Mempengaruhi Peminatan Penumpang Angkutan Laut dan Angkutan Penyebrangan.Forum Teknik Jilid 23, 1999.

[3] Sugiyono, Metode Penelitian Pendidikan Pendekatan Kuantitatif, kualitatif, dan R\&D. 2010

[4] Jhon H Frans, et al, Evaluasi dan Penembangan Kapasitas Termial Bus Kota Kupang, 2017.

[5] Tamin, O.Z., Perencanaan dan Pemodelan Transportasi, Edisi 2, 2000.

[6] A. Soimun, Analisis Probabilitas Perpindahan Moda Pengguna Kendaraan Pribadi ( Sepeda Motor Dan Mobil ) Ke Kereta Api Commuter Surabaya Sidoarjo Analysis Of Probability Of Private Vehicles Users ( Motor Cycles And Cars ) Move To Railway Commuter Surabaya, 2018 